\title{
Flow Injection- Spectrophotometric Determination of Vancomycin Hydrochloride in Pharmaceutical Preparations Using Diazotized Metoclopramide
}

\author{
Mouyed Q. Al-Abachi, Hind Hadi and Fadi J. Yousef* \\ Department of Chemistry, College of Science, Baghdad University, Al-Jaderia, Baghdad-Iraq. \\ "E-mail: fadi.janan@yahoo.com.
}

\begin{abstract}
A batch and flow injection analysis (FIA) spectrophotometric methods have been developed for the determination of vancomycin hydrochloride (VHC) in aqueous solution and in pharmaceutical preparations. The methods are based on the reaction of $\mathrm{VHC}$ with diazotized metoclopramide (DMCP) in alkaline medium. The water soluble yellowish-orange color product was measured at $\lambda \max 451 \mathrm{~nm}$. Linearity was observed from 0.5 to 100 and 1 to $550 \mu \mathrm{g} \mathrm{mL}^{-1}$ of VHC with detection limits of 0.230 and $0.419 \mu \mathrm{g} \mathrm{mL}^{-1}$ by batch and FIA procedure respectively. The sampling rate was 128 injections per hour for flow injection methods. The effects of chemical and physical parameters have been carefully considered and the proposed procedures were successfully applied to the determination of VHC in pharmaceutical formulations.
\end{abstract}

Keywords: Spectrophotometric; Flow injection analysis; Vancomycin hydrochloride; Metoclopramide.

\section{Introduction}

Vancomycin is a glycopeptide antimicrobial substance or mixture of glycopeptides produced by the growth of certain strains of Amycolatopsis orientalis (Nocardia orientalis, Strptomyces orientalis), or by any other means [1]. Vancomycin hydrochloride (VHC) consists principally of the monohydrochloride of $(3 \mathrm{~S}, 6 \mathrm{R}, 7 \mathrm{R}, 22 \mathrm{R}$, 23S,26S,30aSa,36R,38aR)-3-(2-amino-2oxoethyl) -44-[[2-O-(3-amino-, 3,6-trideoxy-3O-methyl- $\alpha$-L-lyxo- hexopyranosyl) - $\beta$ - D glucopyranosyl] oxy]-10,19-dichloro- 7,22, $28,30,32$ - pentahydroxy $-6-[[(2 \mathrm{R})$-4- methyl -2- (methylamino) pentanoyl] amino]2,5,24,38,39- pentaoxo-2,3,4,5,6,7,23,24,25, 26,36,37,38,38a-tetradecahydro- $22 \mathrm{H}-8,11: 18$, 21-dietheno-23, 36(iminomethano)- 13, 16:31, 35- dimetheno- $1 H, 13 H$-[1,6,9] oxadiazacyclohexadecino $[4,5-m] \quad[10,2,16]$ benzoxadiazacyclotetracosine-26-carboxylic acid [2]. Vancomycin was introduced in 1958 as an antibiotic active against Gram-positive cocci, particularly streptococci, staphylococci and pneumococci. It is not active against Gramnegativebacteria, Vancomycin hydrochloride is recommended for use when infections fail to respond to treatment with the more common antibiotics or when the infection is known to be caused by a resistant organism, it is particularly effective for the treatment of endocarditis caused by Gram-positive bacteria [3]. VHC is officially recognized in B.P [2] and U.S.P [4].

A survey of literature revealed that few methods based on visible spectrophotometry for VHC $[5,6,7]$ have been reports. Other methods include HPLC [8,9,10,11], Polarography [12], Capillary electrophoresis [13], Radioimmunoa- ssay [14], Fluorescence polarization immunoassay [15] and Flow injection analysis [16, 17]. This paper describes the batch and flow injection methods for spectrophotometric determination of vancomycin hydrochloride (VHC) by the diazotization-coupling reaction between $\mathrm{VHC}$ and diazotized metoclopramide (DMCP) in the presence of sodium hydroxide. It has been satisfactorily applied for the determination of vancomycin hydrochloride in pure and injections preparations, the reaction can be carried out in batch and FIA and the two approaches were compared.

\subsection{Reaction mechanism of the method}

Vancomycin hydrochloride forms a yellowish-orange colored product ( $\lambda \max$ at $451 \mathrm{~nm}$ with a molar absorption coefficient of $4.620 \times 10^{4} \mathrm{~L} \cdot \mathrm{mol}^{-1} \cdot \mathrm{cm}^{-1}$ ) with DMCP in alkaline medium. The aromatic amino group 
present in metoclopramide is diazotized with nitrous acid $\left(\mathrm{NaNO}_{2} / \mathrm{HCl}\right)$ and the resultant diazonium salt (I) is coupled with VHC at room temperature to form yellowish-orange colored product (II) in alkaline medium (sodium hydroxide) according to scheme.1. The yellowish-orange dye product was only formed in alkaline medium since $\mathrm{VHC}$ is converted into its salt (phenoxide ion). The latter is more stable than phenol (resonance) leading to a more stable intermediate with DMCP [18].

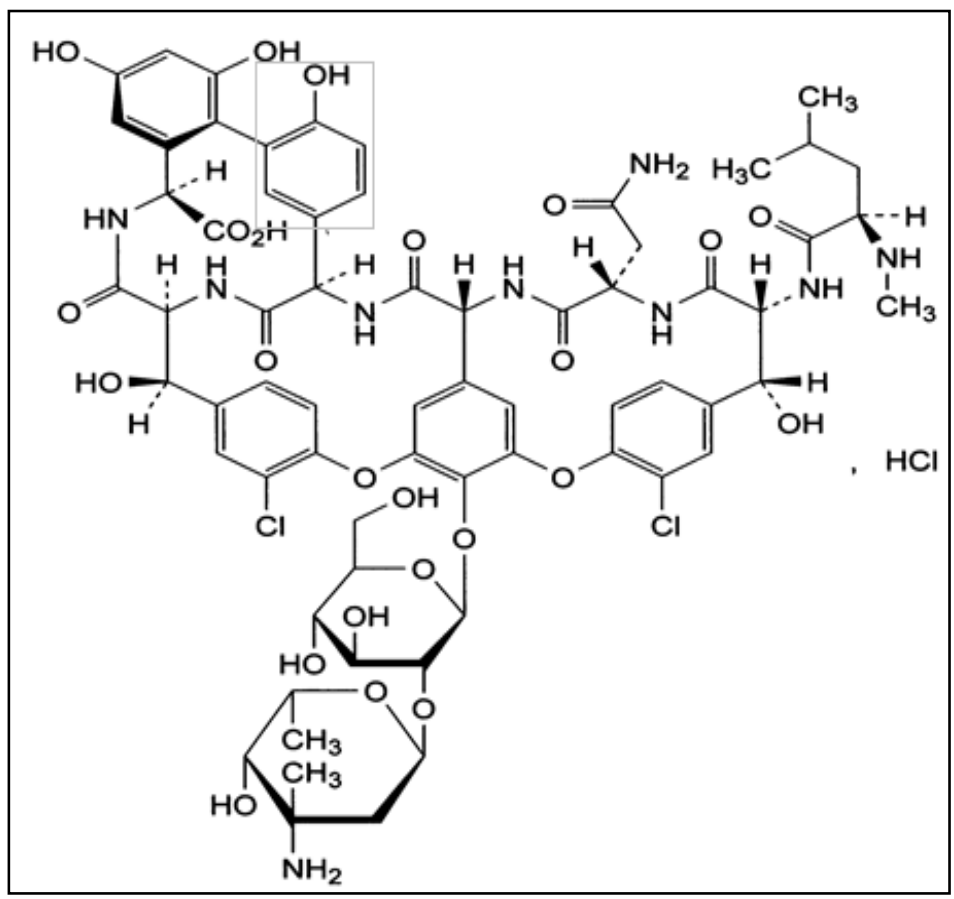

Vancomycin hydrochloride (VHC).

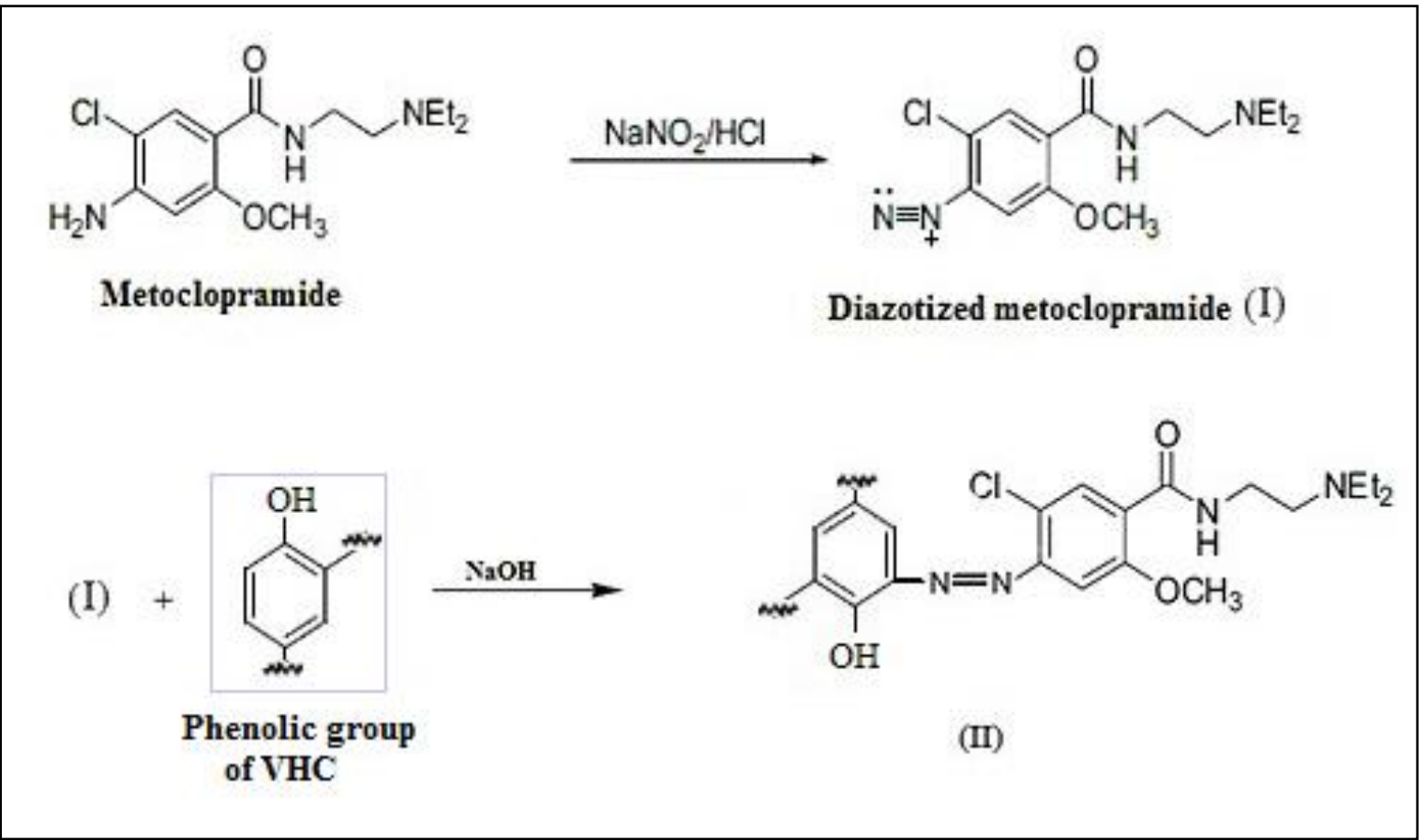

Scheme (1) Proposed mechanism of the reaction between VHC and DMCP in alkaline medium. 


\subsection{Apparatus}

All spectral and absorbance measurements were carried out using a digital double beam spectrophotometer (shimadzu, UV-vis 260). A silica cells were used for the absorbance measurements of the batch procedure. A flow cell $50 \mu \mathrm{L}$ internal volume and $1 \mathrm{~cm}$ bath length was used for the absorbance measurements of FIA. A peristaltic pump (Ismatec, Laborechnik Analytik, CH8152, Zurich, Switzerland) was used to transport the solution.

In addition, an injection valve (Rheodyne, Altex 210, Supelco, USA) was employed to provide appropriate injection volumes of standard solutions and samples while a flexible vinyl tubing $(0.5 \mathrm{~mm}$ internal diameter $)$ was used for the peristaltic pump. The reaction coil (RC) was of Teflon material with an internal diameter of $0.5 \mathrm{~mm}$. The solutions were propelled by peristaltic pump with initial total flow rate of $1.5 \mathrm{~mL} \cdot \mathrm{min}^{-1}$ in the flow injection method, and the absorbance was measured at $451 \mathrm{~nm}$.

\subsection{Reagent and materials}

All the chemicals used were of analytical grade and all the solutions were prepared with distilled water, freshly prepared solutions were always used.

Standard vancomycin hydrochloride VHC solution: stock solution $\left(1000 \mu \mathrm{g} \cdot \mathrm{mL}^{-1}\right)$ was prepared daily by dissolving $0.1 \mathrm{~g}$ of the pure compound (Molecular weight of VHC is 1485.71 g. $\mathrm{mol}^{-1}$ ) in $100 \mathrm{~mL}$ of distilled water and serial dilutions with distilled water were made.

Sample vancomycin hydrochloride VHC solution: the contents of five vials (three commercial sources) were mixed. An aliquot corresponding to $0.1 \mathrm{~g}$ of $\mathrm{VHC}$ was diluted to $100 \mathrm{ml}$ with distilled water in a volumetric flask to obtain $1000 \mu \mathrm{g} \cdot \mathrm{mL}^{-1}$ of VHC. More dilute solutions of pharmaceutical preparations for batch and FIA procedures were made up by simple dilution with distilled water.

Diazotized metoclopramide (DMCP) (Industries and Medical Appliance, SDI, Samara, Iraq): a solution of $2 \mathrm{mM}$ was prepared daily by dissolving $0.0708 \mathrm{~g}$ of metoclopramide hydrochloride (Molecular weight of metoclopramide hydrochloride is
354.3 g.mol $^{-1}$ ) [2] in distilled water.Then, a volume of $1 \mathrm{~mL}$ of $1 \mathrm{M}$ hydrochloric acid $(\mathrm{HCl}$ $(\mathrm{BDH}))$ was displaced in a $100 \mathrm{~mL}$ volumetric flask. The mixture was then cooled to a bout $0-5{ }^{\circ} \mathrm{C}$ using an ice bath for $5 \mathrm{~min}$. This was followed by adding $0.0138 \mathrm{~g}$ of sodium nitrite (Molecular weight of sodium nitrite is 69 g. $\mathrm{mol}^{-1}$, Merck) to the mixture with continuous stirring. After $5 \mathrm{~min}$, the volume was made up to the $100 \mathrm{~mL}$ mark with distilled water and several dilutions were prepared with distilled water.

Sodium hydroxide $\mathrm{NaOH}$ (Merck) solution: stock solution of $1 \mathrm{M}$ was prepared by dissolving $10 \mathrm{~g}$ of $\mathrm{NaOH}$ in $250 \mathrm{~mL}$ distilled water, and working solutions were prepared by appropriate dilution of the stock solution.

\subsection{Procedure}

\subsubsection{General batch procedure}

Aliquots of standard VHC solution containing $12.5-2500 \mu \mathrm{g}$ of $\mathrm{VHC}$ was transferred into a series of $25 \mathrm{~mL}$ standard flasks. A volume of $2 \mathrm{~mL}$ of $2 \mathrm{mM}$ of DMCP and $3 \mathrm{~mL}$ of $50 \mathrm{mM} \mathrm{NaOH}$ solution were added. The contents of the flasks were diluted to the mark with distilled water, mixed well and left for $15 \mathrm{~min}$. The absorbance was measured at $451 \mathrm{~nm}$ (at room temperature $25^{\circ} \mathrm{C}$ ) against reagent blank containing all materials except VHC. A calibration graph was drawn and the regression equation was calculated. For the optimization of conditions and in all subsequent experiments, a solution of $500 \mu \mathrm{g}$ was used in a final volume of $25 \mathrm{~mL}$ $\left(20 \mu \mathrm{g} \cdot \mathrm{mL}^{-1}\right)$.

\subsubsection{General FIA procedure}

Working solutions of $\mathrm{VHC}$ in a range of 1-550 $\mu \mathrm{g} . \mathrm{mL}^{-1} \quad\left(6.730 \times 10^{-4}-0.370 \quad \mathrm{mM}\right)$ were prepared from the stock solutions $\left(1000 \mu \mathrm{g} \cdot \mathrm{mL}^{-1}\right)$. A $200 \mu \mathrm{L}$ portion of VHC was injected into the stream of $1 \mathrm{mM}$ DMCP and was then combined with a stream of $10 \mathrm{mM} \mathrm{NaOH}$ solution with a total flow rate of $2.5 \mathrm{~mL} \cdot \mathrm{min}^{-1}$ and reaction coil length of $100 \mathrm{~cm}$ Fig.(1). The resulting absorbance of the produced was measured at $451 \mathrm{~nm}$. Moreover, optimization of conditions was carried out using $50 \mu \mathrm{g} . \mathrm{mL}^{-1}$ of VHC. 


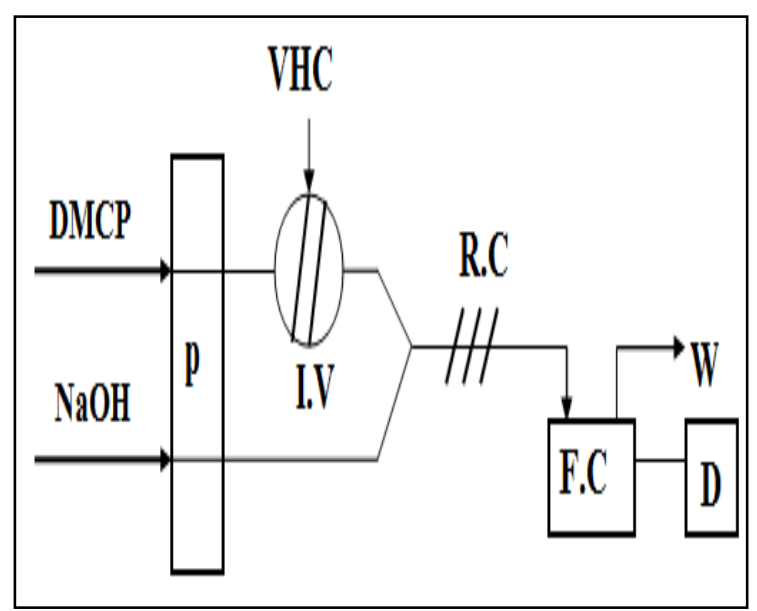

Fig.(1) Schematic diagram of flow injectionSpectrophotometric analysis $P$, Peristaltic pump; I.V, Injection valve; R.C, Reaction coil; F.C, Flow cell; D, Detector

(vis-spectrophotometric); W, Waste.

\section{Results and Discussion}

\subsection{Absorption spectra}

VHC forms a yellowish-orang colored product $\left(\lambda_{\max }\right.$ of $451 \mathrm{~nm}$ with a molar absorption coefficient of $4.620 \times$ $10^{4} \mathrm{~L} \cdot \mathrm{mol}^{-1} \cdot \mathrm{cm}^{-1}$ ) with DMCP in alkaline medium. The absorption spectra of the colored product are given in Fig.(2).

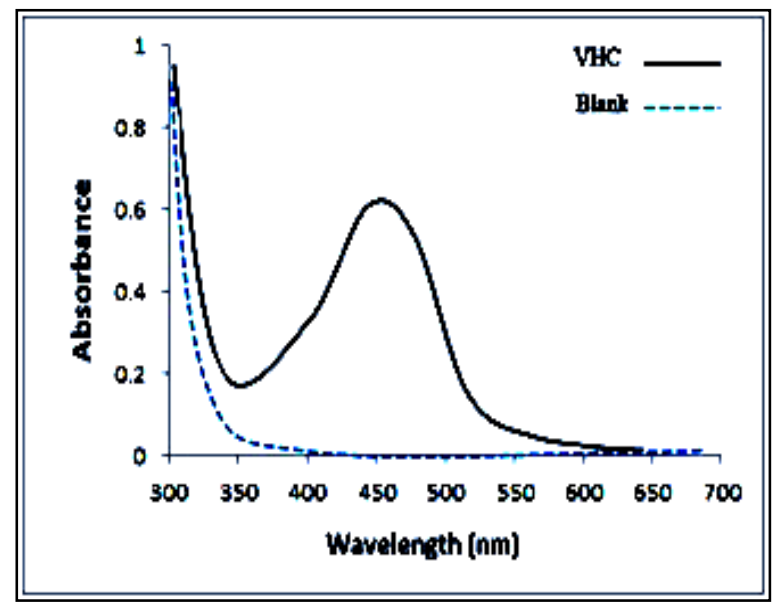

Fig.(2) Absorption spectra of $\left(20 \mu g . m L^{-1}\right)$ $V H C$ treated as described under procedure (1 $\mathrm{mL}$ of $\mathrm{HCl}(1 \mathrm{M}), 2 \mathrm{~mL}$ of DMCP (2 mM) and $3 \mathrm{~mL}$ of $\mathrm{NaOH}(50 \mathrm{mM})$ in final volume $25 \mathrm{~mL}$ ) and measured against reagent blank and the reagent blank measured against distilled water.

The stoichiometry of the reaction between each VHC and DMCP was investigated under the recommended optimum conditions by Job's method [19] according to the following procedure: into a series of $25 \mathrm{~mL}$ volumetric flasks, a decreasing volumes (10 to $0.0 \mathrm{~mL}$ ) of $3.365 \times 10^{-4} \mathrm{M}$ of DMCP were added, followed by adding increasing volumes $(0.0$ to $10 \mathrm{~mL})$ of VHC of same concentration, and $3 \mathrm{~mL}$ of $50 \mathrm{mM} \mathrm{NaOH}$ solution. The solutions were diluted to the mark with distilled water, allowed to stand for $15 \mathrm{~min}$, and the absorbance was measured versus reagent blank at $451 \mathrm{~nm}$. The plot Fig.(3) reached a maximum value at a mole fraction of 0.5 indicating that the reaction proceeds with mole ratio 1:1 for DNPH: VHC.

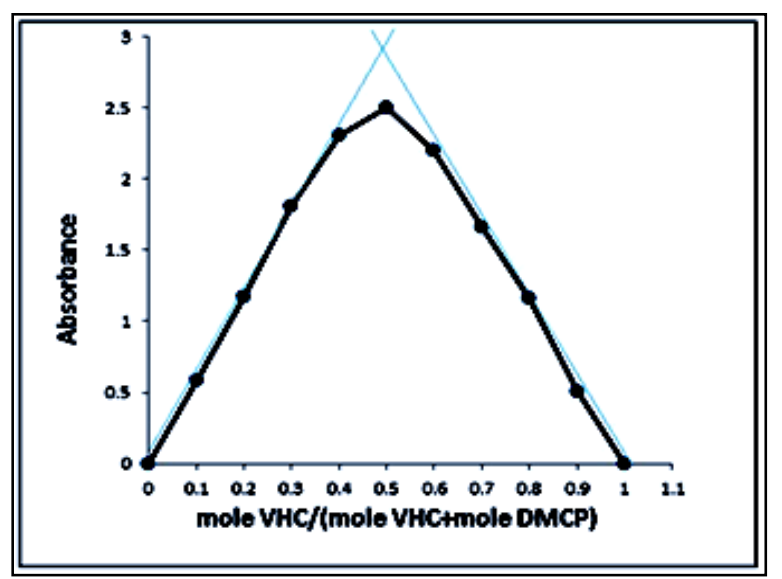

Fig.(3) The mole ratio of the reaction between VHC and DMCP.

\subsection{Batch spectro photometric determination}

The parameters affecting mainly the sensitivity and stability of the colored product were studied and optimized. Optimum conditions were established by changing onefactor-at-a-time (OFAT) and keeping the others fixed by observing the effect produced on the absorbance of the colored species. The yellowish-orange colored product which was formed between VHC and DMCP had developed only in alkaline medium; therefore, the effects of different alkaline solutions were studied such as sodium acetate, sodium carbonate, ammonium hydroxide and sodium hydroxide. The maximum sensitivity and stability were obtained only when the reaction was carried out in the presence of sodium hydroxide solution. The best experimental conditions for the determination of VHC were established for $\mathrm{HCl} 1 \mathrm{M}$ (from 0.3 to $6 \mathrm{~mL}$ ) which was used in diazotization of reagent, DMCP $2 \mathrm{mM}$ (from 0.3 to $6 \mathrm{~mL}$ ) and sodium hydroxide $50 \mathrm{mM}$ (from 0.3 to $6 \mathrm{~mL}$ ) by varying OFAT to a fixed concentration of 
VHC $\left(20 \mu \mathrm{g} \cdot \mathrm{mL}^{-1}\right)$ while the others were kept constant in a final volume of $25 \mathrm{~mL}$ and measuring the absorbance at $451 \mathrm{~nm}$ as shown in following Fig.(4).

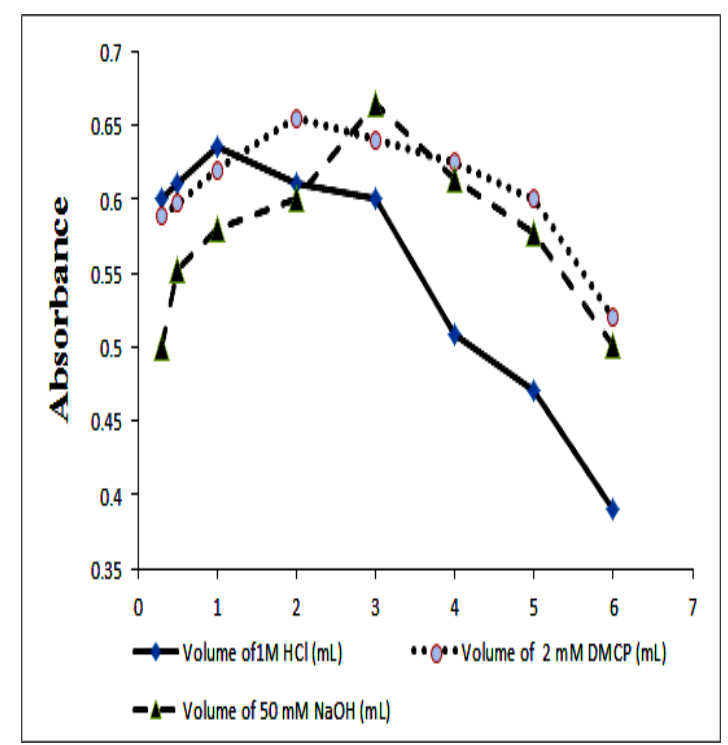

\section{Fig.(4) Effect of volume of $\mathrm{HCl}, \mathrm{DMCP}$ and $\mathrm{NaOH}$ on the absorbance of the colored product.}

The colored product is formed immediately and becomes stable after $15 \mathrm{~min}$ and remains for more than $180 \mathrm{~min}$. The order of addition of the reagents is an essential part of the experiment, it was found that the order of addition of the reagent cited under general procedure (2.3.1) gave maximum color intensity and a minimum absorbance of the blank and was used in all subsequent experiments. The effect of temperature on the color intensity of the dye was studied. A high absorbance was obtained when the color is developed at room temperature $\left(25^{\circ} \mathrm{C}\right)$ than the calibrated flasks were placed in an ice bath at $\left(0{ }^{\circ} \mathrm{C}\right)$ or in a water bath at $\left(45^{\circ} \mathrm{C}\right)$.

The stability constant of the dye products was calculated [20] by comparing the absorbance of a solution containing stoichiometric amount of VHC and DMCP $\left(3.365 \times 10^{-4} \mathrm{M}\right)$ with that of solution containing five-fold excess of DMCP reagent. The stability constant of the dye products in water under the described experimental conditions was $1.303 \times 10^{5} \mathrm{~L}^{\mathrm{mol}}{ }^{-1}$.

The optimum conditions for batch method are incorporated in Table.1, and the effect of excipients on the recovery of VHC is incorporated in Table (2). The regression equation obtained from a series of VHC standards, and the analytical figures of merits of this procedure are summarized in Table (3).

\subsection{Influence of excipients}

Despite the fact that vancomycin is more used in the pure form, however, in order to assess the possible analytical applications of the proposed method, the influence of four common excipients: starch, talc, lactose and poly vinyl pirrolidone (pvp) was studied by analyzing synthetic sample solutions containing $20 \mu \mathrm{g} \cdot \mathrm{mL}^{-1}$ of $\mathrm{VHC}$ and excess amounts (10-fold excess) of each excipient, none of these substances interfered seriously in the determination of VHC by the proposed methods Table (2). 
Table (1)

Optimum conditions established in batch method.

\begin{tabular}{|c|c|c|}
\hline Parameter & Optimum range & Conditions in procedure \\
\hline$\lambda_{\max }(\mathrm{nm})$ & $300-700$ & 451 \\
\hline $\begin{array}{l}\text { Effect of volume of }(1 \mathrm{M}) \mathrm{HCl} \\
\text { solution required }\end{array}$ & $0.3-6 \mathrm{~mL}$ & $1 \mathrm{~mL}$ \\
\hline $\begin{array}{l}\text { Effect of volume of }(2 \mathrm{mM}) \\
\text { DMCP solution required }\end{array}$ & $0.3-6 \mathrm{~mL}$ & $2 \mathrm{~mL}$ \\
\hline $\begin{array}{l}\text { Effect of volume of }(50 \mathrm{mM}) \\
\mathrm{NaOH} \text { solution required }\end{array}$ & $0.3-6 \mathrm{~mL}$ & $3 \mathrm{~mL}$ \\
\hline Type of reaction medium & $\begin{array}{c}\text { Alkaline, acidic, and } \\
\text { neutral }\end{array}$ & Alkaline \\
\hline Type of alkaline medium & $\begin{array}{c}\mathrm{NaOH}, \mathrm{NH}_{4} \mathrm{OH}, \\
\mathrm{Na}_{2} \mathrm{CO}_{3}, \mathrm{CH}_{3} \mathrm{COONa}\end{array}$ & $\mathrm{NaOH}$ \\
\hline Effect of Addition Order & $\begin{array}{l}\mathrm{VHC}, \mathrm{DMCP} \text { and } \mathrm{NaOH} \\
\end{array}$ & $\mathrm{VHC}+\mathrm{DMCP}+\mathrm{NaOH}$ \\
\hline Effect of temperature & $0-45^{\circ} \mathrm{C}$ & $25^{\circ} \mathrm{C}$ \\
\hline $\begin{array}{l}\text { Stability period after final } \\
\text { dilution }\end{array}$ & $1-200 \min$ & $\begin{array}{l}\text { The colored product is } \\
\text { formed immediately and } \\
\text { becomes stable after } 15 \\
\text { min and remains for more } \\
\text { than } 180 \mathrm{~min} \text {. }\end{array}$ \\
\hline
\end{tabular}

Table (2)

Effect of excipients $\left(200 \mu \mathrm{g} . \mathrm{mL}^{-1}\right)$ on the recovery of $\mathrm{VHC}\left(20 \mu \mathrm{g} . \mathrm{mL}^{-1}\right)$.

\begin{tabular}{|c|c|c|c|}
\hline Excipient & Conc. $\boldsymbol{\mu g} \cdot \boldsymbol{m l}^{\mathbf{I}}$ & Error \% & Recovery \% \\
\hline \hline Starch & 19.710 & -1.438 & 98.561 \\
\hline Talc & 19.726 & -1.366 & 98.633 \\
\hline Lactose & 19.801 & -0.991 & 99.008 \\
\hline PVP & 19.610 & -1.950 & 98.050 \\
\hline
\end{tabular}

\subsection{FIA Spectrophotometric determination}

The batch method for the determination of VHC was adopted as a basis to develop FIA procedure. The manifold used for the determination of VHC was designed to provide different reaction conditions for magnifying the absorbance signal generated by the reaction of VHC with DMCP and in sodium hydroxide medium. Maximum absorbance intensity was obtained when the VHC solution was injected into a stream of DMCP and was then combined with the stream of $\mathrm{NaOH}$ Fig.(1). The influences of different physical or chemical parameters on the intensity of the colored product were optimized as follows:

\subsubsection{Optimization of reagents concentration}

The effects of various concentrations of DMCP in the range (0. 01-4 $\mathrm{mM}$ ) were investigated. A concentration of $1 \mathrm{mM}$ of DMCP gave the highest absorbance and was chosen for further use Fig.(5 a). $\mathrm{HCl}$ acid was found necessary for diazotization of DMCP. The effect of HCL was studied in the volume range of $1 \mathrm{M} \mathrm{HCl}$ (from 0.3 to $6 \mathrm{~mL}$ ) and greatest absorbance intensity was obtained with $1 \mathrm{~mL}$ Fig. $(5 \mathrm{~b})$. Therefore, the effect of various concentrations of $\mathrm{NaOH}$ was similarly studied in the concentration range of $(1-80 \mathrm{mM})$ and the greatest absorbance intensity was obtained with $10 \mathrm{mM}$ Fig.(5 c). 

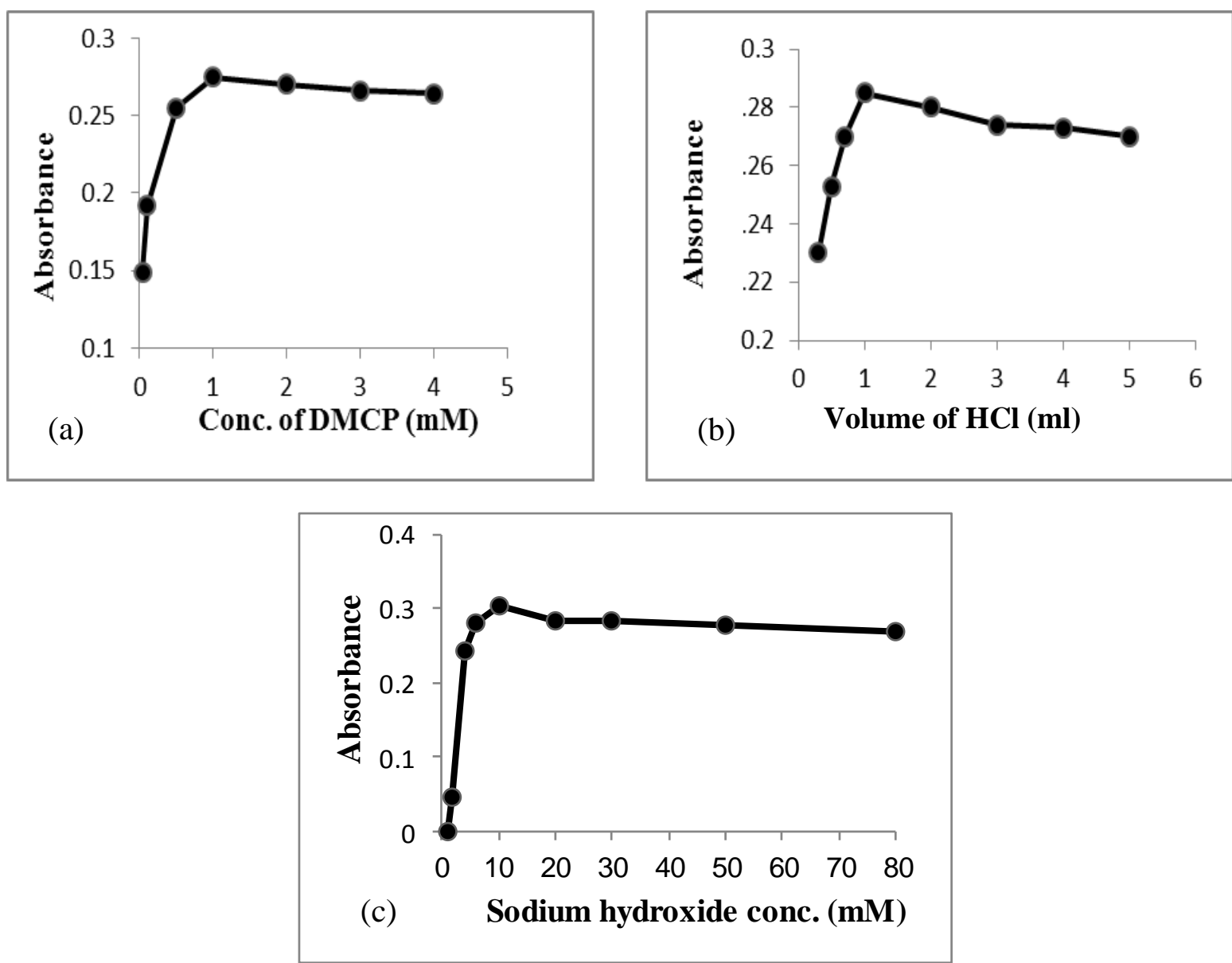

Fig.(5) Effect of reagents concentration on FIA (a) Effect of concentration of DMCP (1 mL of $\mathrm{HCl}(1 \mathrm{M})$ and $\mathrm{NaOH}(50 \mathrm{mM})$ ) (b) Effect of volume of $1 \mathrm{M} \mathrm{HCl}(\mathrm{DMCP}(1 \mathrm{mM})$ and $\mathrm{NaOH}$ (50mM)) (c) Effect of concentration of $\mathrm{NaOH}(1 \mathrm{~mL}$ of $\mathrm{HCl}(1 \mathrm{M})$ and $\mathrm{DMCP}(\mathrm{mMM}))$.

\subsubsection{Optimization of manifold parameters}

The variables studied under the optimized reagents concentrations were the flow rate, the injected sample volume and the reaction coil length. The results showed that a flow rate of $2.5 \mathrm{~mL} \cdot \mathrm{min}^{-1}$ gave the highest absorbance Fig.(6 a) and it was used in all subsequent experiments. The volume of the sample was varied between 50 and $250 \mu \mathrm{L}$ using different lengths of sample loop and showed that a sample of $200 \mu \mathrm{L}$ gave the best absorbance Fig. (6 b). Moreover, a coil length of $100 \mathrm{~cm}$ gave the highest absorbance Fig.(6 c) and was used in all subsequent experiments. A standard calibration graph, obtained from a series of VHC standards and the main analytical figures of merits of the developed procedures are indicated and compared in Table (3).

\subsection{Analytical application}

The precision of the methods was evaluated by analyzing pure samples of VHC and a good recovery was obtained Table (3).
The proposed methods were applied successfully to the analysis of some pharmaceutical preparations containing VHC (Injection and oral use), and they gave a good accuracy and precision as shown in Table (4). The results obtained by the proposed and reference methods [2] for dosage forms were compared statistically by means of the F-test and t-test [21] and were found not to differ significantly in precision and accuracy between the proposed methods and the official methods Table (5). 

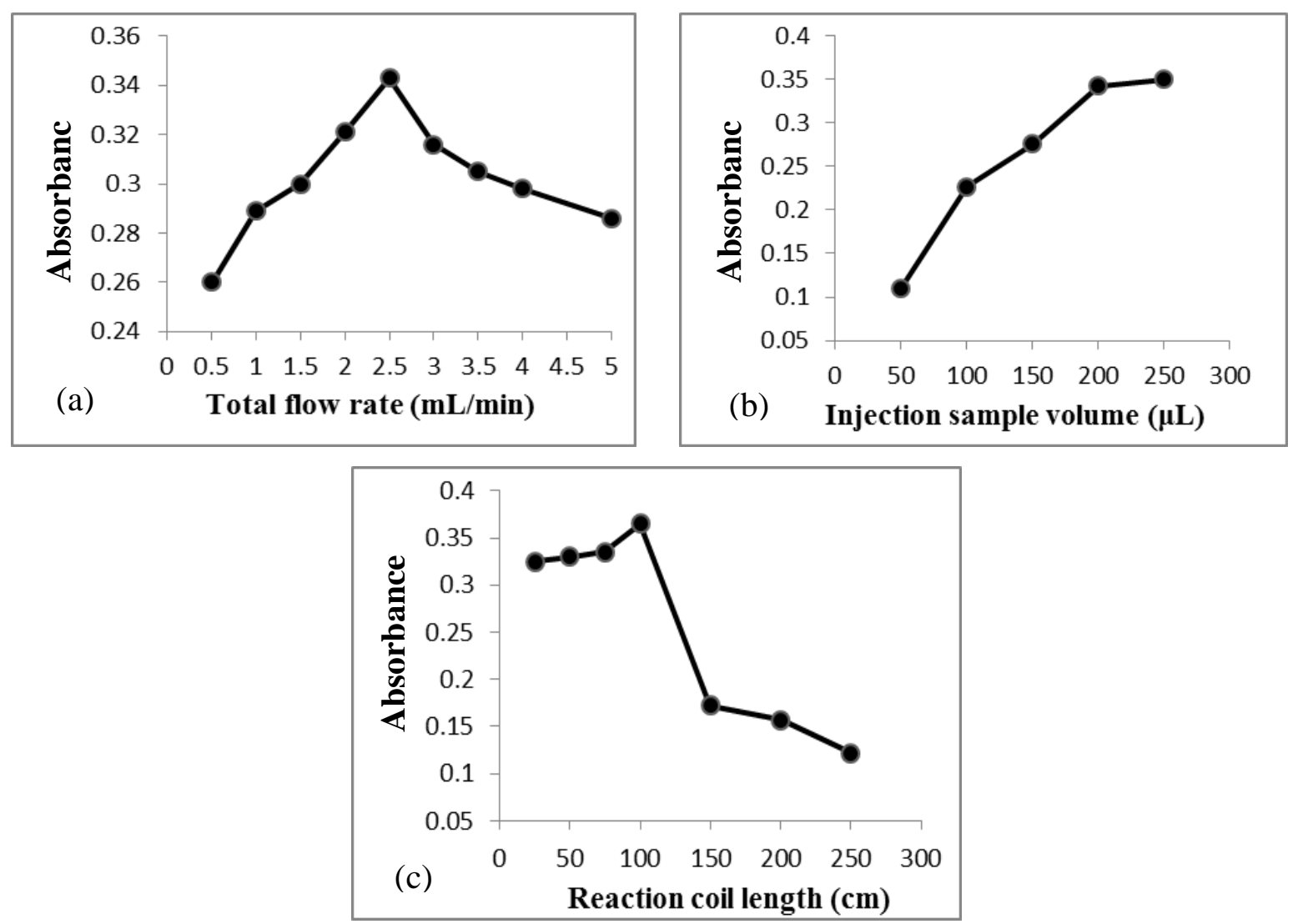

Fig.(6) Effect of manifold parameters on FIA in the presence of $1 \mathrm{~mL}$ of $\mathrm{HCl}(1 \mathrm{M}), \mathrm{DMCP}$ (1mM) and $\mathrm{NaOH}(10 \mathrm{mM})$ (a) Effect of total flow rate (b) Effect of injection sample volume (c) Effect of reaction coil.

Table (3)

Analytical characteristics of the procedures developed for the determination of $\mathrm{VHC}$.

\begin{tabular}{|c|c|c|}
\hline Parameter & Batch procedure & FIA procedure \\
\hline Regression equation & $\mathrm{y}=0.0311 \mathrm{x}-0.0095$ & $y=0.0058 x+0.0402$ \\
\hline $\begin{array}{l}\text { Molar absorption coefficient } \\
\left(\text { L. } \mathrm{mol}^{-1} \mathrm{~cm}^{-1}\right)\end{array}$ & $4.6205 \times 10^{4}$ & $8.6171 \times 10^{3}$ \\
\hline Linearity range $\left(\mu \mathrm{g} \cdot \mathrm{mL}^{-1}\right)$ & $0.5-100$ & $1-550$ \\
\hline Correlation coefficient & 0.9999 & 0.9995 \\
\hline Sy/x & $1.12276 \times 10^{-2}$ & $3.8146 \times 10^{-2}$ \\
\hline $\mathrm{Sa}$ & $5.0405 \times 10^{-3}$ & $1.7450 \times 10^{-2}$ \\
\hline $\mathrm{Sb}$ & $9.25922 \times 10^{-5}$ & $5.9675 \times 10^{-5}$ \\
\hline Sandell's sensitivity $\left(\mu \mathrm{g} . \mathrm{cm}^{-2}\right)$ & 0.03215 & 0.1724 \\
\hline Reproducibility $(\%) *($ RSD \%) & 0.363 & 1.164 \\
\hline Recovery\%* & 100.789 & 99.591 \\
\hline Error $\%^{*}$ & +0.789 & -0.407 \\
\hline Limit of detection $\left(\mu \mathrm{g} \cdot \mathrm{mL}^{-1}\right)^{* *}$ & 0.2306 & 0.4192 \\
\hline Through-put (1/h) & 4 & 128 \\
\hline
\end{tabular}

*The reproducibility, recovery and error of each method was tested by analyzing five replicate samples containing 20 , 40, $80 \mu \mathrm{g} . \mathrm{mL}^{-1}$ of pure VHC for batch method and 50, 300,500 $\mu \mathrm{g} . \mathrm{mL}^{-1}$ of pure VHC for FIA method.

RSD Relative standard deviation.

Sy/x Standard deviation of the residuals.

Sa Standard deviation of the intercept.

$\mathrm{Sb}$ Standard deviation of the slope.

** Limit of detection $=3 S D_{B} / b, S D_{B}$ is the standard deviation of the absorbance $(n=10)$ of the blank determinations $\left(S D_{B}=2.39 \times 10^{-3}\right.$ and $8.104 \times 10^{-4}$ for batch and FIA methods respectively), $b$ is the slope of the corresponding calibration curve). 
Table (4)

Application of the proposed methods to the determination of $\mathrm{VHC}$ in dosage forms.

\begin{tabular}{|c|c|c|c|c|c|c|}
\hline \multirow{2}{*}{$\begin{array}{c}\text { Pharmaceutical } \\
\text { preparation }\end{array}$} & \multirow{2}{*}{$\begin{array}{l}\text { Proposed } \\
\text { methods }\end{array}$} & \multicolumn{2}{|c|}{ Conc. $\mu g . m L^{-1}$} & \multirow{2}{*}{$E \%$} & \multirow{2}{*}{ Rec. \% } & \multirow{2}{*}{$R S D \%$} \\
\hline & & Present & Found* & & & \\
\hline \multirow{2}{*}{$\begin{array}{l}\text { Vancomycin } \\
\text { Hydrochloride }\end{array}$} & \multirow{3}{*}{ Batch } & 20 & 19.622 & -1.688 & 98.311 & 0.262 \\
\hline & & 50 & 48.762 & -2.475 & 97.524 & 0.193 \\
\hline \multirow{4}{*}{$\begin{array}{l}\text { For Solution For } \\
\text { Infusion } \\
\text { Wockhardt UK } \\
\text { 500mg and } 1 \mathrm{~g}\end{array}$} & & 80 & 77.700 & -2.873 & 97.126 & 0.713 \\
\hline & \multirow{3}{*}{ FIA } & 50 & 49.965 & -0.068 & 99.931 & 0.507 \\
\hline & & 100 & 99.620 & -0.379 & 99.620 & 0.408 \\
\hline & & 300 & 299.275 & -0.241 & 99.758 & 0.960 \\
\hline \multirow{6}{*}{$\begin{array}{c}\text { Vancolon }^{(2)} \\
\text { Vancomycin } \\
\text { Hydrochlorid } \\
\text { Injection } \\
\text { Julphar UAE } \\
500 \text { mg and } 1 \mathrm{~g}\end{array}$} & \multirow{3}{*}{ Batch } & 20 & 20.112 & +0.562 & 100.562 & 0.516 \\
\hline & & 50 & 49.790 & -0.418 & 99.581 & 0.183 \\
\hline & & 80 & 79.083 & -1.145 & 98.854 & 0.548 \\
\hline & \multirow{3}{*}{ FIA } & 50 & 51.344 & +2.689 & 102.689 & 0.223 \\
\hline & & 100 & 102.206 & +2.206 & 102.206 & 0.435 \\
\hline & & 300 & 303.586 & +1.195 & 101.195 & 1.085 \\
\hline \multirow{6}{*}{$\begin{array}{c}\text { Vondem }^{(3)} \\
\text { Vancomycin } \\
\text { Hydrochloride } \\
\text { For Solution For } \\
\text { Infusion DEMO } \\
\text { S.A. Greece } 500 \mathrm{mg}\end{array}$} & \multirow{3}{*}{ Batch } & 20 & 20.209 & +1.045 & 101.045 & 0.255 \\
\hline & & 50 & 48.665 & -2.668 & 97.331 & 0.239 \\
\hline & & 80 & 78.376 & -2.029 & 97.970 & 0.296 \\
\hline & \multirow{3}{*}{ FIA } & 50 & 49.793 & -0.413 & 99.582 & 0.604 \\
\hline & & 100 & 99.793 & -0.206 & 99.793 & 0.679 \\
\hline & & 300 & 302.034 & +0.678 & 100.678 & 0.402 \\
\hline
\end{tabular}

* Mean of five measurements of each method, (1), (2), (3) three commercial sources of VHC.

Table (5)

The comparison of the proposed method with standard method.

\begin{tabular}{|c|c|c|c|c|c|c|c|}
\hline \multirow{3}{*}{$\begin{array}{c}\text { Pharmaceutical } \\
\text { preparation }\end{array}$} & \multicolumn{6}{|c|}{ Proposed methods } & \multirow{3}{*}{$\begin{array}{c}\begin{array}{c}\text { Standard } \\
\text { method[2] }\end{array} \\
\text { Rec. \% } \\
\end{array}$} \\
\hline & \multicolumn{3}{|c|}{ Batch } & \multicolumn{3}{|c|}{$F I A$} & \\
\hline & Rec. \% & $t^{*}$ & $F^{*}$ & Rec.\% & $t$ & $F$ & \\
\hline VHC pure & 100.789 & \multirow{4}{*}{1.273} & \multirow{4}{*}{2.141} & 99.591 & \multirow{4}{*}{0.330} & \multirow{4}{*}{2.953} & 100.000 \\
\hline $\begin{array}{l}\text { Vancomycin }^{(1)} \\
\text { Hydrochloride }^{2}\end{array}$ & 97.653 & & & 99.769 & & & 98.343 \\
\hline Vancolon $^{(2)}$ & 99.665 & & & 102.03 & & & 102.697 \\
\hline Vondem $^{(3)}$ & 98.782 & & & 100.017 & & & 101.853 \\
\hline
\end{tabular}

* Theoretical values at $95 \%$ confidence limit, $n_{1}=n_{2}=4, t=2.45$ where $t$ has $v=n 1+n 2-2$ degrees of freedom $=6, F=9.277$ where $F$ has $v_{1}=n_{1}-1, v_{2}=n_{2}-1$ degrees of freedom $=3$ 


\section{Conclusions}

The proposed methods are simple and costeffective for determination of VHC. They are adequate in aqueous solution and in pharmaceutical samples at a concentration level of traces $\left(\mu \mathrm{g} . \mathrm{mL}^{-1}\right)$ without the need for previous separation steps, temperature or $\mathrm{pH}$ control. The procedures have also good linearity, rapid, through-put 128 sample of FIA at hour, sensitivity and economical value compared to othermethods.

\section{Reference}

[1] Sweetman, S. C.; "Martindale, The Complete Drug Reference"; 36th Edition; Pharmaceutical Press; pp 358; 2009.

[2] British Pharmacopeia; The Stationary Office on behalf of the Medicines and Healthcare Products Regulatory Agency (MHRA), London; 2009.

[3] Block, J. H.; Beale, J. M.; "Wilson and Gisvold's Textbook of Organic Medicinal and Pharmaceutical Chemistry"; 11th Edition; Lippincott Williams and Wilkins; pp. 355; 2004.

[4] United States Pharmacopeia 30, National Formulary 25; U. S. Pharmacopeial Convention, Rockville, USA; 2007.

[5] Fooks, J. R.; McGilveray, I. J.; Strickland, R. D.; "Colorimetric assay and improved method for identification of vancomycin hydrochloride"; J. Pharm. Sci. 57, 314317, 1968.

[6] El-Ashry, S. M.; Belal, F., El-Kerdawy, M. M.; Elwasseef, D. R.; "Spectrophotometric Determination of Some Phenolic Antibiotics in Dosage Forms"; Mikrochim. Acta 135, 191-196, 2000.

[7] Sastry, C. S. P.; Rao, T. S.; Rao, P. S. N. H.; Prassa, U. V.; "Assay of Vancomycin and Dobutamine Using Sodium Metaperiodate"; Mikrochim. Acta 140, 109-118, 2002.

[8] Del Nozal, M. J.; Bernal, J. L.; Pampliega, A.; Marinero, P.; López, M. I.; Coco, R.; "High-performance liquid chromatographic determination of vancomycin in rabbit serum, vitreous and aqueous humour after intravitreal injection of the drug"; J. Chromatogr. A 727, 231-238, 1996.
[9] Diana, J.; Visky, D.; Roets, E.; Hoogmartens, J.; "Development and validation of an improved method for the analysis of vancomycin by liquid chromatography: Selectivity of reversedphase columns to wards vancomycin components"; J. Chromatogr. A 996, 115131, 2003.

[10] Forlay-Frick, P.; Fekete, J.; "Comparison of Selected Stationary Phases for Determination of Vancomycin and Ciprofloxacin Using Buffered Mobile Phases, With and Without Triethylamine"; J. Liq. Chromatogr. Relat. Technol. 27, 123, 2004.

[11] Saito, M.; Santa, T.; Tsunod, M.; Hamamoto, H.; Usui, N.; "An automated analyzer for vancomycin in plasma samples by column-switching highperformance liquid chromatography with UV detection"; Biomed. Cromatogr. 18, 735-738, 2004.

[12] Belal, F.; El-Ashry, S. M.; El-kerdawy, M. M.; El-Wasseef, D. E.; "Voltametric Determination of Vancomycin in Dosage Forms through Treatment with Nitrous Acid"; Arzneim. Forsch 51; 763-768, 2001.

[13] Kitahashi, T.; Furuta, I.; "Determination of vancomycin in human serum by micellar electrokinetic capillary chromatography with direct sample injection"; Clin. Chim. Acta 312, 221-225, 2001.

[14] Ackerman, B. H.; Berg, H. G.; Strate, R. G.; Rostschafer, J. C.; "Comparison of radioimmunoassay and fluorescent polarization immunoassay for quantitative determination of vancomycin concentrations in serum" J. Clin. Microbiol. 18, 994-995, 1983.

[15] Hermida, J.; Zaera, S.; Tutor, J. C.; "Therapeutic Drug Monitoring in the COBAS Integra 400 Analyzer"; Ther. Drug Monit. 23, 725, 2001.

[16] Chabenat, C.; Andre, D.; Boucly, P.; "Formation d'un chelate cuivrevancomycine: application au dosage de l'antibiotique en flux continu et detection amperometrique"; Talanta 30, 963-966, 1983. 
[17] Vila, M. M. D.; Salomão, A. A.; Tubino, M.; "Flow injection analysis of vancomycin"; Ecl. Quím, São Paulo 33, 67-72, 2008.

[18] Salem, H.; "Selective spectrophotometric determination of phenolic $\beta$-lactam antibiotics in pure forms and in their pharmaceutical formulations"; Anal. Chim. Acta 515, 333-341, 2004.

[19] Braunm, R. D.; "Introduction to instrumental analysis"; Mc-Graw-Hill, New York; 1987.

[20] Al-Abachi, M. Q.; Al-Ghabsha, T. S.; Salih, E. S.; " Application of promethazine hydrochloride as a chromogenic reagent for the spectrophotometric determination of aniline and its substituents"; Micro. Chem. J 41, 64-71, 1990.

[21] Miller, J. N.; Miller, J. C.; "Statistics and Chemometrics for Analytical Chemistry"; 4th Edition; Pearson Education Limited, London; 2000.

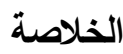

يتضمن البحث نطوير طريقتين طيفيتين باستخدام نظام

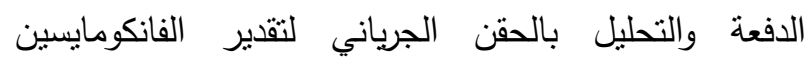
هيدروكلورايد في المحاليل المائية والمستحضرات الصيدلانية. تعتمد الطريقتان على تفاعل الفانكومايسين هيدروكلورايد مع في ولئ كاشف الميتوكلوبرامايد المؤزوت في الوسط القاعدي. تم قياس

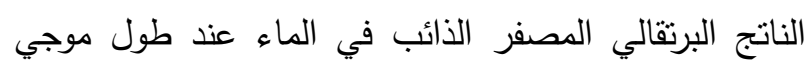
451 نانومتر • بلغت مديات الخطية من 0.5 الى 100 ومن 1 الى 550 مايكروغرام.مل-1 وبحدود كشف بلف من 0.230 و0.419 مايكروغرام.مل-1 لطريقتي الدفعة والحقن الجرياني على التوالي. بلغ معدل النمذجة 128 نموذج بالساعة لطريقة الحقن الجرياني. تمت دراسة تاثير جميع المتغيرات الفيزيائية

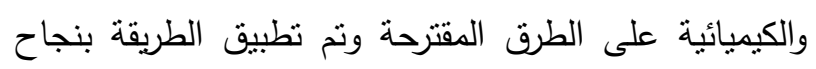

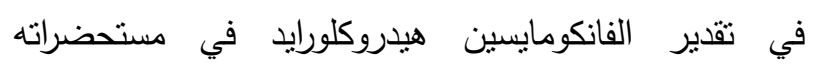
الصبدلانية. 